\title{
THE EFFECT OF WAR ON PRE-EXISTING CONTRACTS INVOLVING ENEMY NATIONALS
}

\author{
SIDNEY A. DIAMOND †
}

IN the normal course of business, United States citizens and corporations have entered into contracts directly or indirectly involving commercial relations with,alien citizens and corporations. Upon the outbreak of war some of these aliens became our enemies, and continued performance of contracts with them or for their benefit became unlawful without specific license. ${ }^{1}$ Although non-resident enemy aliens are denied access to our courts for the duration of the war, ${ }^{2}$ the running of the statute of limitations against them is tolled for that period. ${ }^{3}$ A considerable amount of litigation may

† Special Assistant to the Attorney General of the United States. The opinions expressed herein represent the personal views of the author and do not necessarily reflect those of the Department of Justice.

1. 40 Stat. 412 (1917), 50 U. S. C. App. $\$ 3$ (a) (1940); General Ruling No. 11, as amended, 8 FED. REG. 12287 (1943), 9 FED. REG. 7379 (1944).

2. 40 Stat. 417 (1917), id. at 1021 (1918), 50 U. S. C. App. $\$ 7$ (1940); Ex parte Don Ascanio Colonna, 314 U. S. 510 (1942) ; Rothbarth v. Herzfeld, 179 App. Div. 865, 167 N. Y. Supp. 199 (1st Dep't 1917), aff'd withost opinion, 223 N. Y. 578, 119 N. E. 1075 (1918). The denial applies equally to allies of enemies, who are not themselves at war with this country. Sundell v. Lotmar Corp., 44 F. Supp. 816 (S. D. N. Y. 1942). Corporations domiciled in enemy or enemy-occupied territory are barred. H. P. Drcwry, S. A. R. L., v. Onassis, 266 App. Div. 292, 42 N. Y. S. (2d) 74 (1st Dep't 1943) ; cf. Sovfracht v. Van Udens Scheepvaart. [1943] A. C. 203. But if a corporation in enemy-occupied territory has transferred its domicile to non-enemy territory by virtue of an emergency decree and the government-in-exile is recognized, the disability does not apply. Chemacid, S. A., v. Ferrotar Corp., 51 F. Supp. 756 (S. D. N. Y. 1943) ; cf. The Pamia, [1943] 1 All Eng. Rep. 269 (P.). Eneny nationals not resident in enemy or enemyoccupied territory are unrestricted in their access to the courts. Ex parte Kawato, 317 U. S. 69 (1942) ; Petition of Bernheimer, 130 F. (2d) 396 (C. C. A. 3d, 1942); Clarke v. Morey, 10 Johns. 69, 72 (N. Y. 1813). An enemy or ally of an enemy may defend an action in our courts. 40 StAT. 417 (1917), id. at 1021 (1918), 50 U. S. C. App. \$7 (1940); The Pietro Campanella, 47 F. Supp. 374 (D. MId. 1942); The Santa Lucia, 44 F. Supp. 793 (S. D. N. Y. 1942); State $e x$ rel. Biering v. District Court, 140 P. (2d) 583 (Mont. 1943). Indeed, he must defend unless he can show that the state of war will materially impair the conduct of the defense. Horvath v. Mitsubishi Shoji Kaisha, Ltd., 178 Misc. 52, 33 N. Y. S. (2d) 8 (Sup. Ct. 1942).

3. 40 Stat. 418 (1917), 50 U. S. C. App. $\$ 8$ (1940); Hanger v. Abbott, 6 Wall 532 (U. S. 1867) ; First National Bank v. Anglo-Oesterreichische Bank, 37 F. (2d) 564 (C. C. A. 3d, 1930); Borovitz v. American Hard Rubber Co., 287 Fed. 368 (N. D. Ohio 1923); Afric v. Alaska United Gold Mining Co., 6 Alaska 540 (1922); Kolundjija v. Hanna Mining Ore Co., 155 Minn. 176, 193 N. W. 163 (1923); Siplyak v. Davis, 276 Pa. 49, 119 At1. 745 (1923). 
therefore be anticipated to follow the resumption of relations with enemy countries. The most pressing question may then be whether the outbreak of war terminated the contractual obligations where enemies were involved, or merely suspended them for the period during which the parties occupied the status of belligerents.

Under Section $S$ of the Trading with the Enemy Act of 1917, a United States citizen or corporation may abrogate a contract with an enemy national, by serving notice upon the Alien Property Custodian, if the contract falls into one of two specific categories. The first category includes all agreements containing clauses which provide for their own cancellation or acceleration on notice. Under the second class fall agreements providing for the delivery of anything produced in the United States to an enemy or ally of an enemy, either during or after the war. However, the propriety of identifying the Alien Property Custodian now in office by virtue of a Presidential order ${ }^{6}$ with the Alien Property Custodian created by Section 6 of the Trading with the Enemy Act of $1917^{\circ}$ is by no means clear. The question of whether Section $\delta$ is applicable to the present war has not yet been adjudicated. ${ }^{\text {. }}$

It might have been anticipated that the determination of whether a contract should be suspended rather than abrogated would turn upon the interpretation of the language of Section 3(a) of the Trading with the Enemy Act, ${ }^{8}$ which makes it "unlawful" to "trade" " with an enemy or ally of an enemy. Actually, however, only one reported case basing its decision on the statute has been found. ${ }^{10}$ Since with this single exception the courts have treated the problem as one of common law, ${ }^{11}$ this article will not deal with the interpretation of the Trading with the Enemy Act.

4. 40 Stat. 418 (1917), 50 U. S. C. App. \& \& (1940).

5. Exec. Order No. 9005, 7 Fed. Rec 1971 (1942); Exec. Ordes No. 9193, 7 Frd. Reg. 5205 (1942) ; Doctarents Pertaining to Forejgn Fusdos Costrtol (U. S. Treas. Dep't 1943) 10. The World War I Office of Alien Property Custodian was abolished and its functions transferred to the Department of Justice by ExEc. Onons No. 6694 (1934). These functions were transferred to the World War II Office of Alien Property Custodian by EXEC. ORDER No. 9142, 7 FED. REg. 2985 (1942).

6. 40 Stat. 415 (1917), 50 U. S. C. App. §6 (1940).

7. See Dewey, Foreign Funds and Properly Control-The Pouters and Duties of the Alien Property Custodian (1943) 11 Geo. WAsr. L. Rev. 357, 365.

8. 40 STAT. 412 (1917), 50 U. S. C. App. \$3(a) (1940).

9. Section 2 of the Act defines the words "to trade" to include "(c) Enter into, carry" on, complete, or perform any contract, agreement or obligation ... (e) To have any form of business or commercial communication or intercourse with." 40 SrAs. 412 (1917), 50 U. S. C. App. $\$ 2$ (1940).

10. Compare Springer v. Garvan, 276 Fed. 595 (S. D. Ohio 1920) with s.c. on final hearing, id. at 599.

11. Compare Strauss v. Schweizerische Kreditanstalt, 45 F. Supp. 449 (S. D. N. Y. 1942). 
One type of contract may be disposed of briefly at the outset. If the contract is wholly executed on one side, so that the only remaining obligation is the payment of a debt, that obligation is suspended for the duration of the war and will revive upon the termination of hostilities. ${ }^{12}$ This rule applies to debts which have been reduced to judgment, ${ }^{13}$ to promissory notes, ${ }^{14}$ and to a right of action for damages arising from a breach which took place before the war. ${ }^{15}$ These situations involve remedies rather than rights, in the sense that payment rather than performance is sought. The distinction is an important one, ${ }^{16}$ because it makes the issues in these cases resemble problems of adjective law. Courts will suspend what is left of such contracts without intellectual difficulties, in much the same manner as the "right" of access to the court is treated.17

On the other hand, cases involving incomplete performance of the primary obligation-that is, executory contracts in the strict sense-have called forth involved, confusing opinions ${ }^{18}$ with a variety of results. An English critic suggests that, "A good deal of confusion has been introduced in this matter by premature attempts to generalize before enough cases had arisen to enable a general outline of the relevant principles to be worked out." ${ }^{10}$ With fewer wars in our own history, the criticism is applicable with at least as much force to the American cases. Nevertheless, since the British and American courts adopted very divergent approaches and evolved the law differently, the law in each country is better discussed separately.

\section{The American Cases}

The acknowledged ancestor of almost all American cases dealing with the effect of war on executory contracts is a lengthy and excessively learned opinion by Chancellor Kent of New York. ${ }^{20}$ He decided merely that tran-

12. Zimmerman v. Hicks, 7 F. (2d) 443 (C. C. A. 2d, 1925), aff'd sub nom. Zimmerman v. Sutherland, 274 U. S. 253 (1927); see New York Life Ins. Co. v. Statham, 93 U. S. 24, 31 (1876) ; Neumond v. Farmers Feed Co., 244 N. Y. 202, 206, 155 N. E. 100 (1926); Wullsston, Contracts (rev. ed. 1936) § 1748. The English cases are in accord; Flindt v. Waters, 15 East 260 , 104 Eng. Rep. R. 842 (K. B. 1812) ; Ex parte Boussmaker, 13 Ves. 71, 34 Eng. Rep. R. 221 (Ch. 1806); see Zinc Corporation v. Hirsch, [1916] 1 K. B. 541,556 (C. A.).

13. Birge-Forbes Co. v. Heye, 251 U. S. 317 (1920).

14. See Rhederei A. G. v. Clutha Shipping Co., 226 Fed. 339, 342 (D. Md. 1915).

15. See Ertel Bieber \& Co. v. Rio Tinto Co., [1918] A. C. 260, 269.

16. Compare McNair, Effect of War upon Contracts (1942) 27 Transactions GroTIUS SOCIETY 182, 183, 200.

17. See note 2 supra.

18. Compare Hall, Effect of War on Contracts (1918) 18 CoL. L. REv. 325, 344.

19. McNair, supra note 16 , at 183.

20. Griswold v. Waddington, 16 Johns. 438 (N. Y. 1819); cf. The Rapid, 8 Cranch 155 (U. S. 1814). 
sactions in commercial paper between citizens of the United States and Great Britain during the War of 1812 were void; but in the course of his opinion, the Chancellor reviewed cases and text-writers in America, England and the European continent, thus producing dicta which have stimulated judges ever since. Kent traced Anglo-American jurisprudence on the subject backto the Black Book of the Admiralty, whose origin has been lost in the mists of antiquity. ${ }^{21}$ This venerable authority, as quoted by Kent, declares in Law French that those who "entrecommunent" with the enemy" commit an unlawful act. The English equivalent would presumably be "commune with" or "intercommunicate," but Kent states that the prohibition has always been restricted to intercourse of a commercial character. He bases these views on the theory that a war is between the individual citizens of the nations inrolved, not merely their governments, ${ }^{22}$ finding support in the proposition that a partnership is dissolved by an outbreak of war between the governments of which the partners are citizens. ${ }^{23}$

Numerous courts have followed the Chancellor's precedent of expanding on the subject obiter. Thus one finds many broad statements of this nature:

"By the settled law and policy of this country all executory contracts with enemies of the United States . . . are abrogated by the dechration of war between this country and such enemy." 2s

In fact, an examination of the cases reveals that such language was not at all necessary to their decision, and that the law is actually much more restricted. In this country the general rule appears to be that executory contracts are merely suspended by the outbreak of war; those declared void are the exceptions. ${ }^{25}$

This result has been reached on what may be called a psycholugical basis. Underlying the development of the law concerning trading with the enemy is a feeling that courts should tend to mitigate the harshness of war in its effects on private rights and duties. "The whole tendency of modern law and practice," said the Supreme Court in 1926, "is to soften the 'ancient severities of war,' and to recognize, increasingly, that the nurmal interrelations of the citizens of the respective belligerents are not to be interfered

21. 1 Bouvier, Law Dicrronary (1914 ed.) 360 indicates the doubt, but assigns the work to the reign of Edward III (1327-1377).

22. Griswold v. Waddington, 16 Johns. 438 , $446-449$ (N. Y. 1819); cf. Sutherland v. Mayer, 271 U. S. 272, 287 (1926).

23. Griswold v. Waddington, 16 Johns. 438, 48S et seq. (N. Y. 1819).

24. Rossie v. Garvan, 274 Fed. 447, 450 (D. Conn. 1921) ; cf. Hanger v. Abbott, 6 Wall 532 (U. S. 1867) ; The William Bagaley, 5 Wall 377 (U. S. 1866) ; Pedrick and Springfield, War Measures and Contract Liability (1942) 20 TEx. L. Rev. 710, 731-2.

25. Compare Huberich, Trading yith the Enesy (1918) 261. 
with when such interference is unncessary to the successful prosecution of the war." 26

It has been suggested that the temperate attitude of the United States towards enemies developed early because we are "a country whose lifeblood came from an immigrant stream." ${ }^{27}$ The War of 1812, for example, found many natives of England fighting on the American side. ${ }^{28}$ The Civil War and the general amnesty granted by the President after the rebellion had ceased apparently furthered this sentimental attitude. The "citizens" of the Confederate States were also citizens of the United States ${ }^{20}$ war gave them the status of alien enemies only temporarily. Under such circumstances, judges naturally favored-wittingly or not-reinstatement of the status quo ante bellum wherever possible. ${ }^{30}$ Immediately after World War I, it is true, courts might have been expected to be stricter. Sentimental considerations should not have been present because in that conflict, the alien status of our enemies was clear, and, more significantly, the value and the mechanics of economic warfare were more fully understood. ${ }^{31}$ Nevertheless, the sentimental.attitude had become ingrained and had acquired the force of precedent. It colored the Senate report on the Trading with the Enemy Act of $1917^{32}$ and persists today. ${ }^{33}$

As a corollary to the policy of mitigating the harshness of war, there is implicit in the decisions a tendency to preserve executory contracts whenever possible without conflicting with the absolute requirements of a state of hostilities. In effect, many courts appear to consider executory contracts in general as presumptively subject to suspension rather than cancellation. $^{34}$ Other courts may be motivated by a desire to give the benefit of the doubt to an American citizen in preference to a former enemy.

In effectuating these policies, courts have often justified their result by relying on the "presumed intention" of the contracting parties. Some cases, for example, contain elaborate discussions of the intended disposi-

26. Sutherland v. Mayer, 271 U. S. 272, 237-288 (1926) ; cf. Kershaw v. Kelsey, 100 Mass. 561, 573 (1868); Cohen v. New York Mutual Life Ins. Co., 50 N. Y. 610, 622 (1872).

27. See Ez parte Kawato, 317 U. S. 69, 73 (1942).

28. Ibid. and authorities cited.

29. Compare Littauer, Confiscation of the Property of Technical Enemics (1943) 52 Y ALE L. J. 739, 746.

30. See Cohen v. New York Mutual Life Ins. Co., 50 N. Y. 610, 620 (1872).

31. H. R. Rep. No. 85, 65th Cong., 1st Sess. (1917) 2.

32. Sen. Rep. No. 111, 65th Cong., 1st Sess. (1917) 1, stating that the purpose of the act was "to mitigate the rules of law which prohibit all intercourse between the citizens of warring nations, and to permit, under careful safeguards and restrictions, certain kinds of business to be carried on." The House report, supra note 31, is a curious mixture of this view and a recognition of the importance of economic warfare.

33. See Ex parte Kawato, 317 U. S. 69, 76-7 (1942).

34. See Mutual Benefit Life Ins. Co. v. Hillyard, 37 N. J. Law 444, $468-9$ (1874) ; Sands v. New York Life Ins. Co., 50 N. Y. 626, 635 (1872). 
tion of the subject matter of the contract. But from the wording of the instrument itself, it is often not clear that the parties actually meant what the court assumes they did. ${ }^{35}$

Since it is ordinarily the exceptional case which gives rise to litigation, the language of the decisions does not indicate that suspension is the general rule. Even in cases where the court purported to suspend the agreements, the ultimate result has been termination. Thus in two cases the court held that the obligations were suspended for the duration, but went on to say that whether or not they should be revived depended upon equitable considerations. ${ }^{36}$ But inasmuch as neither contract was actually revived by the court, the result is indistinguishable from that reached in cases holding contracts terminated by the outbreak of war. However, since it appears that executory contracts judicially nullified or terminated fall into restricted categories, the effect of the United States' decisions would seem to be that the ordinary contract involving trading with the enemy is merely suspended.

Contracts Terminated. Executory contracts actually terminated or nullified by the outbreak of war fall into two main categories: (1) contracts whose delayed performance would thwart the purpose of the parties, and (2) contracts whose suspension would interfere with the conduct of the war. In an attempt to establish the boundaries of the general rule, illustrative situations in each class of exceptions will be considered.

Cases holding that contracts whose delayed performance would thwart the purpose of the parties should be terminated, are actually decided on principles of impossibility of performance. Merely to suspend for the duration of the war agreements requiring performance at a more or less definite future time would defeat their purpose, or at least impair the value of the bargain materially. Such contracts are therefore terminated by the outbreak of war.

Contracts of affreightment are peculiarly of this nature. ${ }^{37}$ One such case ${ }^{38}$ goes on the expressed ground that there can be no possible estimate

35. E. g., MTaurer Co. v. Tubeless Tipe Co., 235 Fed. 713 (C. C. A. 6th, 1922); Heidner v. St. Paul \& Tacoma Lumber Co., 124 Wash. 652, 215 Pac. 1 (1923), cort. devicd, 263 U. S. 721 (1924) ; cf. Williams v. Paine, 169 U. S. 55 (1897) ; Zimmerman v. Rosssler, 246 App. Div. 305, 2s9 N. Y. S. (2d) 401 (1st Dep't 1935), aff'd without opinion, 272 N. Y. 566, 4 N. E. (2d) 739 (1936).

A similar device has been used to decide against a party who surtzins a particular view in order to escape from a bad bargain. See Erdreich v. Zimmerman, 190 App. Div. 443,179 N. Y. Supp. 829 (1st Dep't 1926).

36. New York Life Ins. Co. v. Statham, 93 U. S. 24 (1876); Neumond v. Farmers Feed Co., 244 N. Y. 202, 155 N. E. 100 (1926).

37. See Allanvilde Corp. v. Vacuum Oil Co., 248 U. S. 377 (1919); cf. The Kronprinzessin Cecilie, 244 U. S. 12 (1917).

38. Allanwilde Corp. v. Vacuum Oil Co., 248 U. S. 377 (1919). 
of the length of the war. From this premise, the court developed a ruling that the act of one of the parties in repudiation of the contract was justified. This theory was perhaps appropriate to a decision based, as in many of the English cases, ${ }^{39}$ on the doctrine of commercial frustration $;^{40}$ but it would appear to be an unnecessarily flimsy basis for a general statement that all executory contracts should be treated as terminated by war. ${ }^{41}$ It would seem that the court need go no farther than to say that a party is justified in acting on the assumption that any war is of uncertain duration, and hence would refrain from penalizing him for a bad guess unless he did not behave as a reasonable man under the circumstances. ${ }^{42}$

When a supply contract calls for regular shipments at stipulated times, it obviously falls within this first classification. Since delayed performance will not be in accord with the purpose of the parties, the contract will be held cancelled by war. ${ }^{43}$ Occasionally, where no specific time is fixed, the court will hold that shipment in a reasonable time is an implied term in the contract, and treat it as terminated on that basis. ${ }^{44}$ In one of the few American cases thus far litigated in World War II, the contract called for a supply of the buyer's requirements of a particular commodity over a ten-year period which had not yet commenced when war began. Although the only question presented for decision was one of federal jurisdiction, the court clearly intimated in its opinion that itobelieved the contract had been dissolved. ${ }^{45}$

Contracts requiring more or less continuous commercial intercourse between the parties are also in this first class of exceptions to the general rule. A partnership agreement between persons whose status becomes that of reciprocal enemies is the clearest example of this type. Since an international partnership virtually requires constant communication and ordinarily functions by means of frequent transfers of credit and shipments of merchandise, such an agreement is dissolved ipso facto by a declaration of war. ${ }^{46}$

39. See Esposito v. Bowden, 7 E. \& B. 763, 792, 119 Eng. Rep. R. 1440 (Q. B. 1857); Geipel v. Smith, L. R. 7 Q. B. 404,414 (1872).

40. See McNair, Frustration of Contract by War (1940) 56 L. Q. Rev. 173, 203.

41. But see Pedrick and Springfield, supra note 24, at 731-2.

42. Compare MICNair, supra note 40 , at 205.

43. Maurer Co. v. Tubeless Tire Co., 285 Fed. 713 (C. C. A. 6th, 1922).

44. Heidner v. St. Paul \& Tacoma Lumber Co., 124 Wash. 652, 215 Fac. 1 (1923), cert. denied, 263 U. S. 721 (1924).

45. Strauss v. Schweizerische Kreditanstalt, 45 F. Supp. 449 (S. D. N. Y. 1942).

46. Sutherland v. Mayer, 271 U. S. 272, 286, 289 (1926); The William Bagaley, 5 Walt. 377 (U. S. 1866) ; Mayer v. Garvan, 278 Fed. 27 (C. C. A. 1st, 1922) ; Rossie v. Garvan, 274 Fed. 447 (D. Conn. 1921) ; see Hanger v. Abbott, 6 Wall. 532 (U. S. 1867) ; Sorenson v. Sutherland, 27 F. Supp. 44 (S. D. N. Y. 1939), rev'd on other grounds, 109 F. (2d) 714 (C. C. A. 2d, 1940), aff'd sub. nom. Jackson v. Irving Trust Co., 311 U. S. 494 (1941); Monsseaux v. Urquhart, 19 La. Annual Rep. 482, 486 (1867) ; Mutual Benefit Life Ins. Co.v. Hillyard, 37 N. J. Law 444 (1874) ; Griswold v. Waddington, 16 Johns. 438, 488 ff. (N. Y. 1819); Cohen v. New York Mutual Life Ins. Co., 50 N. Y. 610 (1872). 
Numerous statements have been made to the effect that contracts which "necessarily involve intercourse" with an enemy are "dissolved and terminated" by the commencement of hostilities, ${ }^{47}$ but even the partnership casès have been questioned as too dogmatic in this connection. ${ }^{43}$ The modern view is to suspend such contracts when the commercial arrangements are such that the business interrupted by the war can, without thwarting the essential purpose of the partners, be resumed after the treaty of peace has been concluded. ${ }^{49}$

The general principle which emerges from the decisions is that a contract will be terminated only if suspension for the period of the war would involve a substantial alteration of its terms, materially increasing the burden of performance. 50 Statements that agreements which "necessarily involve intercourse" are nullified ${ }^{51}$ are merely a misleading phrasing of the same view. Whether or not frequent intercourse was required during the normal peace-time operation of the contract is not controlling. ${ }^{52}$ The contract will be dissolved only when suspension of commercial intercourse will substantially affect the terms of the bargain ${ }^{63}$ and the very fact of non-performance during the war deprives the other party of the consideration for which he bargained. ${ }^{54}$ The problem is actually one of temporary supervening impossibility; if delayed performance cannot fairly be considered equivalent to the performance specified the contract is discharged.5

The second category of contracts held terminated by the war consists of those whose suspension would interfere with the conduct of the war. Cases

47. See, e.g., Second Russian Ins. Co. v. Mriller, 297 Fed. 404, 410 (C. C. A. 2d, 1924); aff'd, 268 U. S. 552 (1925).

48. See Huberich, op. cit. sipra note 25 , at 282-290.

49. Ibid.

50. Compare Winuston, Contracts $§ \S 1748$, 1958; Restateasenit, Co:itracts (1932) $\S 596$ (c) ; Horton, Effects of War on Contracts (1942) 10 GEo. Wasr. L. REr. 943, 947-8.

51. e.g., Moore, Force Majeure, in Mledres, The Tradinc with the Exeusy AcT (1924) $445,461$.

52. Compare Huserich, op. cit. supra note 25, at $34 t 6$.

53. Although it is weak authority and subject to conflicting interpretations, reference must be made to Hodgskin v. United States, 279 Fed. 85 (C. C. A. 2d, 1922), a criminal prosecution for conspiracy to defraud the United States. It involved a contract between a German corporation and its American subsidiary, under which the German parent company had agreed to supply patent rights, know-how, etc., to the American company; which manufactured products in this country. The bulk of the profits made by the subsidiary was payable directly to the German company, not merely by way of dividends on its stock. The German company had the right to choose the top personnel of the American company. The trial judge charged that this contract had been abrogated is so facto by the declaration of war in 1917. The conviction was affirmed, but this portion of the charge was not assigned as error on the appeal.

54. Compare Hall, supra note 18 , at 344 .

55. Compare Wade, The Principle of Impossibility in Contract (1940) $56 \mathrm{~L}$. Q. Rev. $519,554-555$. 
involving these contracts are actually decided on principles of illegality of performance. The rule is based on the obvious undesirability of aiding the enemy, either directly, by putting things of value in his hands; or indirectly by immobilizing resources or restricting the freedom of action of the contracting party.

For example, a joint venture requiring the shipment of American cotton to a neutral port to be held there for the account of an enemy firm until peace should be declared, was held abrogated by the entrance of the United States into World War I. ${ }^{6 B}$ The theory of the case was that performance of the contract would have prevented the resources of a warring nation from being employed in its own behalf. Somewhat similar, though less dramatic, was the plight of the American shareholders who had executed an option agreement giving enemy nationals the exclusive right to purchase the stock of a corporation located in the United States. This contract was held terminated by the war on the ground that it prevented freedom of action by American citizens. ${ }^{57}$

Gratuitous statements confirming the principle are readily available. The Supreme Court has said, for example, that the basic purpose of prohibiting trade with the enemy is "to preclude the possibility of aid or comfort, direct or indirect, to the opposing forces." is It should be noted, however, that cases of this general nature tend to be based on spurious reasoning. To say that performance of a contract will aid or comfort the enemy is not necessarily equivalent to saying that the contract must be terminated rather than suspended. To be consistent with the underlying principle, the only type of contract which should be abrogated on this basis is one whose suspension will interfere with the conduct of the war. ${ }^{50}$ Among the American cases, such a situation was present only in the two discussed above. ${ }^{60}$

A state court attempted to rest one recent decision ${ }^{61}$ in part on the ground that aid to the enemy was involved, but in view of the facts involved this approach appears questionable with respect to this part of the decision. An American buyer had contracted to purchase certain equipment from an American supplier, specifying that the equipment was to be exported to a subsequent purchaser in Japan. In concluding that the contract of resale

56. Joring v. Harriss, 292 Fed. 974 (C. C. A. 2d, 1923), cert. denied, 263 U. S. 710 (1923).

57. Matheson v. Hicks, 10 F. (2d) 872 (E. D. N. Y. 1926).

58. Sutherland v. Mayer, 271 U. S. 272, 287 (1926) ; cf. Second Russian Ins. Co. v. Mfiller, 297 Fed. 404, 410 (C. C. A. 2d, 1924), aff'd, 268 U. S. 552 (1925); Kershaw v. Kelsey, 100 Mass. 561, 572-573 (1868) ; Sands v. New York Life Ins. Co., 50 N. Y. 626 (1872).

59. Compare Williston, Contracts \$ 1748; Restateunent, Contracts $\$ \$ 594,596$ (b).

60. Joring v. Vams, 292 Fed. 974 (C. C. A. 2d, 1923), cert. denied, 263 U. S. 710 (1923) ; Matheson v. Hidis, 10 F. (2d) 872 (E. D. N. X. 1926).

61. Takahashi v. Pepper Tank Co., 58 Wyo. 330, 131 P. (2d) 339 (1942). 
was dissolved by the outbreak of war and that the original supplier was relieved of his obligation, the court relied on the theory, stated without extended consideration, that the contract contemplated supplying an enemy with materials useful in preparation for war. ${ }^{62}$ There was no discussion of the alternative of suspending the contract for the duration. The court apparently had in mind the type of general statement uttered in cases holding that a contract must be held void because the enemy would be aided if performance were permitted. ${ }^{.3}$ To decide a case of this nature on such a basis seems utterly unrealistic. Japan would undoubtedly have been helped if the shipment had been completed, but the chance of its completion was less than ephemeral. To be sure, there was a theoretical possibility of obtaining a license to trade with the enemy, and conceivably the case could have arisen in such a way that the gesture of applying for such a license would have had to be established. But if the court assumed a real possibility of obtaining the license, it would be taking the inconsistent position of presuming to nullify in advance an act of the executive authorizing the shipment.

The case is actually a good example of a contract which should be suspended unless suspension would thwart the purpose of the parties. The argument in favor of termination, as opposed to suspension, would be the desirability of foreclosing to Japan the possibility of obtaining the goods after the war. Such an argument, however, appears inconsistent with general civilized principles as well as with the thoroughly established AngloAmerican rule that a contract fully executed on one side-where nothing remains unperformed except the payment of money-is merely suspended. $^{65}$ Under the latter rule, the obligation revives automatically at the end of the war, and the former enemy can collect his debt. This decision, therefore, does not seem supportable on the ground of interfering with the conduct of the war. ${ }^{66}$ It should be repeated, however, that the court had available entirely satisfactory alternative theories, which would support its decisions on the particular facts involved.

Contracts Suspended. Contracts held suspended, rather than terminated, by the outbreak of war also fall into groups. The most familiar type is the contract of life insurance. Although there are indications to the contrary, the overwhelming weight of authority refuses to treat a life insur-

62. Id. at 363,131 P. (2d) 339 at 352 .

63. See cases cited, note 1 supra.

64. See sources cited note 1 supra.

65. See Neumond v. Farmers Feed Co., 244 N. Y. 202, 205, 155 N. E. 100 (1926); and other cases cited supra notes 12-15.

66. The English courts have a somewhat different approach. See discussion page ... infra. 
ance contract as dissolved by the war. ${ }^{67}$ The rationale is that the contracts are not commercial in nature and require communication between the parties only for the payment of premiums, an obligation which can be st1spended until after the war without serious consequences to either side.

A second type of contract which should in general be suspended is the contract of agency. Actually, numerous agency contracts have been held completely unaffected by the outbreak of hostilities. In order to avoid both termination and suspension, according to a recent case, the contract must meet these requirements: (1) communication with the enemy must not be required or have occurred, directly or indirectly; and (2) circumstances must disclose the principal's assent to the continued existence of the agency in the event of war. Such consent will be implied if continuance of the agency is to the benefit of the principal. ${ }^{68}$

Favored treatment for agency contracts with enemy principals developed from early cases involving the question of whether interest was suspended by the outbreak of war. It was held in 1818, for example, that interest should be paid to the resident agent of an enemy principal for the periods covered by the Revolutionary War and the War of $1812 .{ }^{.9}$ If a judgment for interest.during the war could be obtained, it was reasoned, the agency itself continued despite the outbreak of hostilities. Safeguards were found in the fact that no commercial intercourse across the line of hostilities was involved. ${ }^{70}$ Thus it has been held that a power of attorney to sell land was not affected by the outbreak of the Civil War, ${ }^{71}$ and that proxies to vote corporate stock remain effective during hostilities. ${ }^{72}$ But the commencement of war may produce such a fundamental alteration in the relations of

67. Mutual Benefit Life Ins. Co. v. Hillyard, 37 N. J. Law 444 (1874); Cohen v. New York Mutual Life Ins. Co., 50 N. Y. 610 (1872) ; Sands v. New York Life Ins. Co., 50 N. Y. 626 (1872). But see New York Life Ins. Co. v. Statham, 93 U. S. 24 (1876) ; cf. Hunericu, op. cit. supra note 25 , at 296 , stating that this case "is not an authority for the proposition that war terminates a contract of life insurance."

68. Aldridge v. Franco-Wyoming Securities Corp., 31 A. (2d)246, 251 (Del. Ch. 1943).

69. Conn. v. Pa., 6 Fed. Cas. 282 (C. C. D. Pa. 1818).

70. See Sutherland v. Mayer, 271 U. S. 272, 288 (1926). Contracts have been held both suspended and completely unaffected on this ground. "Kershaw v. Kelsey, 100 Mass. 561 (1868) (lease between enemies both on same side of line of hostilities held unaffected by war); Springer v. Garvan, 276 Fed. 595 (S. D. Ohio 1920) (contract with enemy to support relatives was here held unaffected; but see s. c. on final hearing, id. at 599); Vorhaus v. City Nat. Securities Co., 167 N. Y. Supp. 736 Sup. Ct. Dep't 1917), aff'd without opinion, 182 App. Div. 922, 169 N. Y. Supp. 1118 (1st Dep't 1918) (trust agreement held stuspended).

71. Williams v. Paine, 169 U. S. 55 (1897).

72. Aldridge v. Franco-Wyoming Securities Corp., 31 A. (2d) 246 (Del. Ch. 1943); Monsseaux v. Urquhart, 19 La. Annual Rep. 482 (1867). 
the parties that the continued authority of an agent will not be assumed in the absence of evidence of the principal's assent. ${ }^{73}$

The interests of society may require that agency contracts continue, despite the outbreak of war, where the supervision of property is necessary to protect it from depreciation ${ }^{74}$ but the ordinary agency contract would seem to require special treatment by the courts no more than does the ordinary commercial contract. A preferable approach is that recently adopted by a New York court. Finding that a power of attorney had been issued to a citizen of the United States by a citizen of Germany residing there, the court made no inquiry into the necessity of communicating across the line of hostilities, but simply ruled that the contract had been suspended by this country's entrance into World War II. ${ }^{75}$ Agency contracts in general seem to be proper cases for suspension.

The great majority of ordinary commercial agreements, other than those requiring performance at a particular time, also belong in the group of contracts suspended by war. This group would include patent licenses, agreements for the interchange of technical information, long-term supply contracts, royalty agreements, under copyrights and the like.

Provisions to Operate in the Event of IT'ar. Of particular interest are the cases involving the effect of agreements containing specific provisions to operate in the event of war. In one such case, a German firm had agreed with its American partner, who operated a branch house in this country, that if war should be declared the German and American establishments should become separate enterprises automatically. A sentence from the court's opinion summarizes the decision:

"The German partners could make no agreement with the complainant after a declaration of war that would be recognized as valid in our courts, and therefore no executory agreement entered into before the war, and in contemplation of it, could be effective to transfer their interest to him [the American partner] ... after war had been declared." 76

A vigorous dissent argued that the agreement took effect eo instanti with the declaration of war, and that the provision in the contract providing for separation of the business was not against public policy. ${ }^{77}$

73. Sutherland v. Mayer, 271 U. S. 272, 297 (1926); if. Williams v. Paine, 169 U. S. 55,73 (1897).

74. See Monsseaux v. Urquhart, 19 La. Annual Rep. 482, 486 (1867).

75. In re Walz, 181 Ifisc. 511, 46 N. Y. Supp. (2d) 589 (Surr. Ct. 1944).

76. Mlayer v. Garvan, 278 Fed. 27, 33 (C. C. A. 1st, 1922).

77. Id. at $35-41$. 
On a different set of facts, a New York court adopted the contrary attitude. ${ }^{78}$ A contract between an individual and a securities firm, both located in this country, for the purchase by the defendant of German marks for future delivery, ${ }^{70}$ provided that payment was to be delayed if "wireless should be interrupted." Taking judicial notice of the political situation at the time the contract was made, which included the possibility of United States' involvement in war, the court construed the quoted language to be equivalent to, or at least to include, "war should be declared." The court gave effect to the clause, holding the defendant liable for the agreed price A vigorous dissent argued that the agreement took effect $e o$ instanti with after communications with Germany had been reëstablished following the armistice.

It should be noted, however, that this case is not direct authority with respect to executory contracts, because the court also found that a sale of the marks had taken place before the declaration of war. Unfortunately, no American case has ruled directly on an executory contract containing a simple suspension clause to become operative automatically in the event of war. ${ }^{80}$ To be consistent with the principles already stated, the contract should be treated as if it contained no such clause. If the contract can be suspended without either thwarting the purpose of the parties or interfering with the conduct of the war, it should be considered suspended. If not, it should be terminated without regard to the suspension clause. Such a clause is entitled to some weight'as an indication that the parties themselves contemplated suspension as an event which would not thwart their essential purpose. If suspending the contract would interfere with the conduct of the war, the suspension clause should be considered void as against public policy, and the entire contract abrogated on that basis.

Two apparently anomalous cases may be explained by the manner in which they arose. United States v. Hamburg-Amerikanische Packetfahrt$A . G{ }^{81}$ was an antitrust action which reached the Supreme Court after the outbreak of World War I in Europe, but prior to this country's entry. An agreement in restraint of trade in ocean carriage was alleged to exist among American, British, German and other foreign companies. The court, taking judicial notice of the European war, dismissed the Government's case without prejudice, on the express ground that the question involved in the action had become moot as "an inevitable legal consequence"

78. Zimmerman v. Roessler, 246 App. Div. 306, 284 N. Y. Supp. 409 (1st Dep't 1935), aff'd without opinion, 272 N. Y. 566, 4 N. E. (2d) 739 (1936).

79. Compare Erdreich v. Zimmerman, 190 App. Div. 443, 179 N. Y. Supp. 829 (1st Dep't 1920).

80. But cf. Rossie v. Garvan, 274 Fed. 447, 452 (D. Conn. 1921) (holding that to treat a standard force majeure clause as sufficient to dissolve an executory contract would be against public policy).

81. 239 U. S. 466 (1916). 
of the war. ${ }^{82}$ Shortly thereafter, another antitrust action arose involving a situation almost identical in outline. ${ }^{83}$ The contracting parties were American, British and German and the alleged restraint of trade was with regard to ocean carriage. The lower court dismissed the bills of complaint on the merits. ${ }^{84}$ The Government moved in the Supreme Court for an order dismissing the bills without prejudice on the ground that the existence of the European war made the question moot at the time the decrees were entered below, and specifically requested application of "the doctrine announced in the Hamburg-American case." 80 Ruling that the contracts had been dissolved "as the result of the European War," the Supreme Court entered the requested order.

It should be noted that at the time either of these cases was decided the United States had not entered the war. Furthermore, no extended consideration was given in either case to the legal principles involved, because none was required. Although in the later case the court stated that the contracts had been dissolved and that it was applying the rule of the HamburgAmerican case, the Hamburg-American case did not itself contain any statement to the effect that dissolution had been effected by the war. The decision apparently proceeded on the ground that the business of the parties had ceased, regardless of whether the contract itself was affected by the war. ${ }^{80}$ Moreover, the cases did not involve any rights of the parties under the contracts. Indeed, both cases recognized that the conditions complained of by the Government might recur after the war and result in a renewal of the antitrust actions.

\section{The English Cases}

The law on executory contracts involving trade with an enemy has developed with much greater clarity in Great Britain than in the United States. Moreover, the English courts have taken a harsher view, establishing cancellation rather than suspension of the contract as the general rule. One reason for the difference is probably the fact that English courts were not subject to the tempering effect which the War of $1812^{87}$ and the Civil War ${ }^{88}$ appear to have had on the development of the American law. Fur-

82. Id. at 475 .

83. United States v. American-Asiatic S. S. Co., 242 U. S. 537 (1917),

84. 220 Fed. 230 (S. D. N. Y. 1915).

85. United States v. American-Asiatic S. S. Co., 242 U. S. 537, 538 (1917).

86. 239 U. S. at 477 ; cf. Richards v. Wreschner, 174 App. Div. 484,156 N. Y. Supp. 1054 (1st Dep't 1916), holding, before the United States entered World War I, that a German company's inability to ship antimony from Belgium to the United States bseause of a state of war between Belgium and Germany was merely impossibility of performance due to foreign law which did not excuse the obligor.

87. See Ex parte Kawato, 317 U. S. 69, 73 (1942).

88. Littauer, loc. cit. sitpra note 29. 
ther, England sustained the propriety of confiscating enemy property in addition to contraband of war at a much earlier date than the United States. ${ }^{89}$

British judges recognize two types of situations which may arise when the parties to an executory contract become enemies. Either continued performance of the contract will involve intercourse with the enemy, or its continued existence will confer upon the enemy an immediate or futture benefit. $^{.0}$ On either theory, the contract is declared terminated by the outbreak of hostilities.

The legal technique used in many of the English cases for reaching such a decision is the doctrine of commercial frustration. This theory assumes that war constitutes such a supervening impossibility that reasonable men could not have entered into the bargain expressed in the contract if they had contemplated the event of war. Admittedly resorting to a fiction, the coturt then holds that the contract contains an "implied term" providing for its own dissolution upon the happening of the event. ${ }^{01}$ A distinguished writer has recently expressed the reasoning in the following language:

"It is submitted that the test can be stated as follows: Would a reasonable man in the position of the party alleging frustration, after taking all reasonable steps to ascertain the facts then available, and without snapping at the opportunity of extricating himself from the contract, come to the conclusion that the interruption was of such a character and was likely to last so long that the performance or further performance of the contract would really amount to the performance of a new contract? If so, there is frustration. And in considering the probability of the duration he is entitled to assume that in so far as the outbreak or the existence of a war is the cause of the interruption that cause is of uncertain duration. Moreover, the Court will not let him suffer for a determination thus reached if subsequent unexpected events show that he was unduly pessimistic in his forecast." 02

89. Id. at 747.

90. In re Badische Co., [1921] 2 Ch. 331.

91. Id. at 379-380; cf. Hirji Mulji v. Cheong Yue S. S. Co., [1926] A. C. 497, 507, 510 (P. C.) ; Bank Line v. Arthur Capel \& Co., [1919] A. C. 435, 455; Metropolitan Water Board v. Dick, Kerr \& Co., [1918] A. C. 119, 127, 131; Tamplin S. S. Co. v. Anglo-Mexican Petroleum Co., [1916] 2 A. C. 397, 403; cf. Allanwilde Corp. v. Vacuum Oil Co., 248 U. S. 377 (1919). There are other theories for the doctrine of commercial frustration, but they have all been reconciled with the "implied term." See McNair, supra note 40, at 178-182. With particular reference to the question of damages, see Fibrosa Spolka Akcyjna v. Fairbairn Lawson Combs Barbour, Ltd., [1943] A. C. 32, overruling Chandler v. Webster, [1904] 1 K. B. 493 (C. A.) and the line of authority developed from the "Coronation cases." Cf. Law Reform (Frustrated Contracts) Act, 1943, $6 \& 7$ GEo. VI, c. 40, which was enacted in response to the suggestion in the Fibrosa case, supra, that legislative clarification was advisable.

92. McNair, supra note 40 , at 205. 
If it is not held abrogated by its own "implied term," a British court will, with rare exceptions, declare the contract void on the ground that the enemy will be benefited by its continued existence. This result is reached even when it is contrary to the express intention of the parties, as where the contract contains a clause specifically calling for suspension rather than cancellation. Such a clause is held void as against public policy on the theory that it is intended to suspend merely the deliveries required under the contract, thus leaving open the necessity-or at least the possibility-of communicating with the enemy. ${ }^{93}$ The leading case on this aspect of the problem bases its decision also on the theory that suspension would tie the hands of the British party to the contract by requiring it to maintain an inventory position sufficient to permit the supply of the required goods as soon as the war terminated ${ }^{94}$-a condition deemed to interfere substantially with Britain's conduct of the war. In view of the basis for the rule, it may be doubted whether the latter theory would have entered British law if the British company had been the purchaser rather than the supplier of the goods. Similarly, doubt may be expressed concerning the validity of an approach based on theoretical benefits accruing to the enemy, ${ }^{95}$ especially if the enemy is a vendor rather than a vendee. It would seem somewhat unrealistic to determine a case of this nature on the ground that the enemy's war potential is increased because the enemy party's credit position is improved by the knowledge that his rights under the contract will reacquire all their original virility with the coming of peace. Still, the sense of the English cases is that "... the suspension of performance until after the war would confer the present value of a post-war benefit upon the enemy. ..." 00

There has been some criticism of the basis for this appruach. For example, the Court of Appeal in 1916 said: "The prohibition against doing anything for the benefit of an enemy contemplates his benefit during the war and not the possible advantage he may gain when peace comes." 97 The extent to which the rule should apply has also been questioned..$^{93}$

93. Ertel Bieber \& Co. v. Rio Tinto Co., [1918] A. C. 260.

94. Ibid.; cf. Zinc Corporation v. Hirsch, [1916] $1 \mathrm{~K}$. B. 541 (C. A.). The line of authority includes Porter v. Freudenberg, [1915] 1 K. B. 857, 866 (C. A.); Robson v. Premier Oil Co., [1915] 2 Ch. 124 (C. A.); Janson v. Driefontein Consolidated Alines, [1902] A. C. 484 ; Esposito v. Bowden, 7 E. \& B. 762,119 Eng. Rep. R. 1430 (Q. B. 1857); Furtado v. Rogers, 3 Bos. \& P. 191, 127 Eng. Rep. R. 105 (C. P. 1802); The Hoop, 1 C. Rob. 196, 165 Eng. Rep. R. 146 (Ga. 1799). Cf. Lindenberger Co. v. Lindenberger, Inc., 235 Fed. 542 (W. D. Wash. 1916) (contract provided that English law governed).

95. Compare In re Badische Co., [1921] 2 Ch. 331.

96. MicNair, supra' note 16 , at 209.

97. Daimler Co., Ltd. v. Continental Tyre and Rubber Co., [1910] 2 A. C. 307, 347, approved in Stevenson \& Sons, Itd. v. Aktiengesellschaft für Cartonnagen-Industrie, [1918] A. C. $239,249$.

98. See Ottoman Bank v. Jebara, [1928] A. C. 269, 276; cf. Tingley v. Mfuller, [1917] 2 Ch. 144,156 (C. A.). 
Actually, the rule that executory contracts must be voided at the commencement of war is not universal in England. It has been pointed out that status-such as the contractual relationship of marriage ${ }^{00}$-remains unaffected by war and that a stockholder's contractual relationship with a corporation would in all likelihood be held merely suspended if the question came before an English court. ${ }^{100}$ But the principal recognized exceptions rest upon a famous dictum of Lord Dunedin in the Rio Tinto case. ${ }^{101}$ It reads as follows :

"There is indeed no such general proposition as that a state of war avoids all contracts between subjects and enemies. Accrued rights are not affected though the right of suing in respect thereof is suspended. Further, there are certain contracts, particularly those which are really the concomitants of rights of property, which even so far as executory are not abrogated. Such as, for instance, the contract between landlord and tenant. . . . In other words, the exectutory contract which is abrogated must either involve intercourse, or its continued existence must be in some other way against public policy as that has been laid down in decided cases." 102

The case Lord Dunedin referred to is Halsey $v$. Lowenfeld ${ }^{103}$ which held that a lease to a non-resident alien enemy was neither terminated nor suspended by the outbreak of war, and that the enemy could be sued for rent during hostilities. A later case held that an irrevocable power of attorney to sell land was not invalidated or suspended by a war which made the donor of the power an enemy. ${ }^{104}$ It will be noted that the coupling of real property with the contract is the key to these cases. ${ }^{105}$

The most recent reported British case on this general subject has led to a considerable clarification of the law. Schering, A.G., a German corporation, had become indebted before the war to the Stockholms Enskilda Bank of Sweden. Later, but also before the war, Schering, Ltd., the English subsidiary of the German company, had entered into a contract with Stockholms Enskilda Bank by which it became bound to discharge its parent's debt to the Bank in instalments at stated times. When Schering, Ltd., failed to pay the instalment which became due after the declaration of war between

99. McNair, supra note 16 , at 199.

100. Id. at 198.

101. Ertel Bieber \& Co. v. Rio Tinto Co., [1918] A. C. 260.

102. Id. at 269.

103. $[1916] 2$ K. B. 707 (C. A.).

104. Tingley v. Müller, [1917] 2 Ch. 144 (C. A.).

105. Compare McNair, supra note 16, at 199. One litigant made an unsuccessful attempt to argue that a contract for the supply of iron ore over a period of 99 years was analagous to a lease and should be treated as a "concomitant of the rights of property." Fried. Krupp A. G. v. Orconera Iron Ore Co., 35 T. L. R. 234 (H. L., 1919). 
England and Germany, the Swedish bank brought suit. It was held in 1941 that the English company could not be permitted or required to discharge its obligation during the period of hostilities, since payment would benefit an enemy. ${ }^{106}$

In January, 1942, Schering, Ltd., brought an action against Stockholms Enskilda Bank for a declaration that the contract had been abrogated by the commencement of the war. The lower court held for the plaintiff, rejecting the contention that the contract was, at most, suspended. ${ }^{107}$ It was recognized that the contract was with a neutral rather than an enemy; but Simonds, J., proceeded on the theory that it was for the benefit of an enemy, and also that its performance necessarily involved commercial intercourse with an enemy. He pointed out that the enemy benefits not only from an increase in his resources, but also from a decrease in ours; and went on to say:

"It may be that there is a class of contract the performance of which is suspended and not abrogated by the outbreak of war, but I cannot myself think of an example unless the contractual right is . . . a concomitant of a proprietary right ${ }^{108}$ as for example a covenant to pay rent may be a concomitant of a leasehold interest or unless the right is an 'accrued right' at the outbreak of war in the sense of a right accrued by' reason of a breach of contract." 103

The decision rests at least in part on the theory that, since the Rio Tinto case ${ }^{110}$ holds that the parties themselves cannot suspend a contract for the duration of the war by their own express language, a fortiori that result could not be reached by "an artifice of the law." 111

On appeal, the Court of Appeal reversed the decision, finding that, in effect, no obligation remained other than the payment of a debt. ${ }^{112}$ The contract would therefore be subject to the general rule covering agreements wholly executed on one side, which are suspended rather than terminated.

The court went farther, however, and carved out an exception from the law on the ground that the contract in this case was with a neutral rather than an enemy. This innovation finds no counterpart in the American cases, and appears to be based on expediency rather than any logical distinction. To justify its apparent departure from precedent, the court point-

106. Stockholms Enskilda Bank v. Schering, Ltd., [1941] 1 K. B. 424 (C. A.).

107. Schering, Ltd., v. Stockholms Enskilda Bank, 59 T. I. R. 208 (Ch. 1943).

108. Citing Lord Dunedin in Ertel Bieber \& Co. v. Rio Tinto Co., [1918] A. C. 260, quoted page ..., supra.

109. Schering, Ltd. v. Stockholms Enskilda Bank, 59 T. L. R. 203, 211 (Ch. 1943).

110. See note 101 supra.

111. Schering, Itd. v. Stockholms Enskilda Bank, 59 T. L. R. 203 (Ch. 1943).

112. Schering, Itd. v. Stockholms Enskildz Bank, [1944] 1 Ch. 13 (C. A.). 
ed out that only one of the cases found by it in the reports ${ }^{113}$ involved a contract with a neutral as distinguished from contracts both parties to which were enemies. Where the alien party is an enemy, the Master of the Rolls stated, there is a necessary presumption that the assets of the enemy country will be enhanced by the continued existence of the contract, and it is therefore abrogated without further inquiry. On the other hand, where the alien party is a neutral, it is necessary to determine whether or not the enemy will actually receive any benefit from the continued existence of the contract. "In cases where the outbreak of war compels the common law to interfere with and control the performance of such contracts on the ground of public policy the measure of interference ought not to exceed what is required by the public interest in regard to the successful prosecution of the war." 11 s

When the contract is with a neutral, the problem becomes a question of fact as to whether performance will aid the enemy. In the Schering case, this question was readily answered in the negative, for the excellent reason that another court had already held payments under the contract to be suspended for the duration. ${ }^{115}$ The court also indicated that a suspension clause in a contract with a neutral would be given effect even though the contract was for the eventual benefit of an enemy. ${ }^{110}$ It is curious to note that the court apparently rejected the "present value of a post-war benefit" theory in so far as executory contracts with neutrals are concerned, while simultaneously reiterating it with regard to contracts between enemies. ${ }^{117}$

In any event, the English rule is now clear. When the executory contract is with an enemy, there is a presumption that its continued existence will enhance the enemy's resources, and the contract is therefore abrogated. If an enemy is involved in the contract, but the actual alien party is a net1tral, the court must determine whether its performance will, in fact, be of benefit to the enemy. If the answer to this question is in the affirmative, the contract will be abrogated; if in the negative, the Schering case implies that performance of the contract will be suspended for the duration. However, barring the peculiar circumstance of another court decision holding the contract suspended, it would seem that a negative answer would justify a decision that the contract could be performed even during war-time. The British distinction between cases involving neutrals and those involving enemies may be useful in certain cases, but it has the obvious disadvantage

113, Esposito v. Bowden, 7 E. \& B. 762, 119 Eng. Rep. R. 1930 (Q. B. 1857).

114. Schering, Ltd. v. Stockholms Enskilda Bank, [1944] 1 Ch. 13, 23 (C. A.); cf. Sutherland v. Mayer, 271 U. S. 272, 287-8 (1926), quoted page ..., supra.

115. Stockholms Enskilda Bank v. Schering, Ltd. [1941] 1 K. B. 424 (C. A.).

116. Schering, Ltd. v. Stockholms Enskilda Bank, [1944] 1 Ch. 13, 25 (C. A.).

117. Id. at 24 . 
of requiring a detailed investigation of the entire transaction when a neutral is a party to the contract.

\section{ConcLusion}

The chief difference between the English and American law on the effect of war on pre-existing contracts involving commercial relations with enemy aliens is that in England these contracts are generally terminated by the outbreak of war while in the United States, with some exceptions, they are suspended. In cases involving contracts where the alien party is a neutral but an enemy is involved, the British courts have recently evolved an exception to their general rule, suspending rather than terminating such contracts if the enemy will not benefit from its performance. American courts depart from their general rule of suspension, and terminate the contract, in two instances: where suspension would either thwart the intention of the parties, or interfere with the conduct of the war.

The relatively inflexible British rule has the advantage of furnishing a definite guide to the contracting parties. This approach, however, may do utter violence to the true intent of the parties and far exceed the security requirements of a nation at war. From a practical point of view, there appears to be no difficulty in assuming that commercial contracts may he entered into with full realization of the possibility of war and the distinct intention to have all intercourse suspended upon its outbreak, hut only until such time as commercial relations between the warring nations may be resumed. Numerous contracts are made to last for extremely long periods, ${ }^{118}$ some even forever. ${ }^{119}$ It seems reasonable to assume that the parties to such contracts honestly intend them to outlast wars, just as they outlast luman lives. Courts should therefore attempt to give effect to the intention of the parties, if it can be determined within the four corners of the contract or by reasonable inference. If on this analysis suspension is found to be the proper result, it should then become a question of fact whether the enemy will receive any direct or indirect benefit from the suspension of the contract. If so, the court should hold suspension to be against public policy and the contract therefore abrogated by the outbreak of war.

118. See United States v. Alba Pharmaceutical Co., Civ. No. 15-363 (S. D. N. Y., complaint filed Sept. 5, 1941) (contract for 50 years, renewable automatically in ten-year periods thereafter) ; United States v. The Bayer Co., Civ. No. 15-364 (S. D. N. Y., complaint filed Sept. 5, 1941) (same); Fried. Krupp A. G. v. Orconera Iron Ore Co., 35 T. L. R. 234 (H. L. 1919) (contract to supply iron ore for 99 years); [AmsiunL] I. G. FARBENINDUSTRIE (1939) 56 (contract with Riebeck'sche Montanuerle effective April 1, 1925, to March 31, 2023; contract with Dynamit A. G. effective January 1, 1926, to December 31, 2024).

119. See United States v. Merck \& Co., Civ. No. 3159 (D. N. J., complaint filed October 28, 1943) ("treaty agreement" "in perpetuity"); FitzGerard, Isidustrua CorsBINATION IN ENGLAND (1927) SI (agreement to supply chemicals in perpetuity). 
From the point of view of economic warfare, also, there are advantages in considering executory contracts with enemies suspended rather than abrogated. If the contracts remain in existence, the rights of the enemy parties are available for seizure by the Alien Property Custodian. This has actually occurred in a number of instances where United States companies are the other contracting parties. ${ }^{120}$ The warring nation is thus in a position to make whatever use of the enemy's contractual rights it deems advisable. If it appears desirable to terminate the contract, the Alien Property Custodian can readily enter into negotiations toward that end. In the United States, it is even possible to cancel such a contract without vesting the rights of the enemy party in the Alien Property Custodian. Section 5(b) of the Trading with the Enemy Act, as presently constituted, permits the President, during wartime or any other period of national emergency, to "nullify ... transactions involving any property in which any foreign country or a national thereof has any interest." 121 Hence, although the American rule that contracts with enemies should generally be suspended grew tup without regard to modern techniques of economic warfare, it is the rule best suited to modern conditions.

120. E.g, the following Vesting Orders published in a single recent issue of the Federal Register: Nos. 3678, 3679, 3680, 3682, 3684, 3685, 3686, 3690, 3691, 3692, 3693, 3694, 9 FED. REG. $7211-7216$ (1944).

121. 55 Stat. 839 (1941); 50 U. S. C. App. $\$ 5$ (b) (Supp. III, 1944); Alexewicz v. General Aniline \& Film Corp., 181 Misc. 181, 43 N. Y. S. (2d) 713 (Sup. Ct. 1943) (employment contract terminated under this provision). It should be noted that the alien party need not be an enemy or ally of enemy to come within this section. 